\title{
The Tendency for Using Accounting Information Systems in Lebanese Firms
}

\author{
Al-Khoury Pierre, Ghazzawi Khalil, Kotob Marwan, Ghanem Nivine, and Atwi Tarek
}

\begin{abstract}
The purpose of this study is to show the impact of Accounting Information System (AIS) on accounting in Lebanese companies. There are many advantages of AIS, yet there are many disadvantages too. One must check an AIS affordability, time saving, additional costs, cash saving, and employees' adaptation. In this research, quantitative study is done in which questionnaires are filled by accountants and accounting managers to see how this community looks to AIS, how it affects accounting, its positive and negative effecst on firms. The most important advantages of AIS are time saving, accuracy, security, and money saving. Still, employees have to adapt quickly with the new information system. AIS affordability, purchase cost and additional costs, are tested.
\end{abstract}

Index Terms-Accounting information systems, information technology, correlation, regression, method model, stepwise method model.

\section{INTRODUCTION}

With the huge development the world is witnessing technologically, firms are experiencing huge and fast changes, and the AIS is a major change. Collecting data that can lead to high quality information is what helps the change and allows the improvement of an international AIS and makes it more successful. This type of information allows better ways of planning, controlling, and decision making [1]-[5]. AIS is a necessity as it's able to transform these dimensions into a financial one [6].

AIS uses formalized categories permitting the transmission of information with fewer symbols, and creates a common language in the organization for members to communicate [7].

This all facilitates the coordination between various functions inside the firm that need to provide input into the process of decision making [6].

Decision to outsource accounting functions involves strategic decisions as well as practical and cost related ones [8], but also relates to strategic accounting functions [9].

Main benefits of JIT (journal information technology) are according to [10], reduced process time and raw material, improved machinery, reduced space, improved products, lower production cost, simple processes with improved quality, better elasticity, skill, inspiration and difficulty solving aptitude of employees, better productivity [11], and increased weight on supplier integration. Reference [12] Computer systems are used by managers in order to support

Manuscript received February 5, 2013; revised April 25, 2013

Al-Khoury Pierre, Ghazzawi Khalil, Kotob Marwan, Ghanem Nivine, and Atwi Tarek are with Rafik Hariri University, Mechref-Lebanon (e-mail: khourypp@rhu.edu.lb, Ghazzawika@rhu.edu.lb). financial data to be able to make accurate and effective decisions. AIS are classified into two categories: First, effective decision-making of information, that is largely for control of organization. Second, to facilitate information, that is mainly used for coordination of organization in decisionmaking process [13]. AIS development and financial performance enhancement will lead to successful troubleshooting cost accounting system. AIS have a comparative advantage in choosing the best alternative instead of consultants and projects.

Using the AIS provides the benefits of adjustment, administration and high confidence level.The impact of AIS on planning, controlling, and decision making processes makes the new technology play a very important role in covering and recording a wide range [14]. AIS financial control involves many factors, and the resulting decision making process got versatile, as well as those decisions. These decisions are taken by relying on different types of reports provided by AIS [3],[15].

\section{LITERATURE REVIEW}

Business onward nowadays is unsettled due to the rapid race of technology, IT investments and globalization. Hence, Lebanese companies must be aware of the IT architecture based on the company's observations and designs. Moreover, a decision making process must take place for companies to have a clear cognition of what they are about to examine. Consequently, the role of information technology (IT) has shifted over the last decades [16], to become playing a critical role for companies to manage and control their resources.

IT investments were and are still utilized to facilitate the toil of accountants at Lebanese institutions, but the IT evolution now is representing an opportunity and a potential risk for the Lebanese accountant.

Prior to 1960's the main role of IT situates was bookkeeping, where their main responsibility was keeping records; however, accountants didn't trust that much, due to the loss of many info that goes by the lack of techs. The new management information system has generated all the information [17], to its relevance, and the accountant became an interpreter of info, so he/she got to deal with the info overload. Also research on management accounting and integrated information systems has evolved across a number of different lines of research. Some place heavier emphasis on the management accounting side, while others emphasize the information systems side [18]. Nonetheless, to be able to understand emerging technologies and anticipate their effects on accounting, we must begin to understand the effects of the most updated technologies [19]. 
Main results for that were:

1) The excessive perfectionism on the part of accountants;

2) Excessive data schemes which make it difficult to understand;

3) Conceptual divergence between accountants and other managers;

4) The lack of interest of other managers.

The journal of economics recognized six barrieris hindering the establishment of AIS in Tehran stock exchange listed companies, and they are as follow: organizational structure barrieirs with 26 percent, middle managers barriers with 26 percent, human resources barriers with 25 percent, environmental factors with 21 percent, organizational culture barriers with 19 percent and finally financial issues with16 percent.

To overcome these barriers financial managers should be well and professionally trained. The most important features of IT are; high speed data processing, high accuracy, high speed access to information, being up-to-date, the abilities of electronic exchange of information, high quality, cheap and tapering costs. Thus, suppliers of information, especially accountants, should provide advanced and high-quality information so that their services could be sold at high prices. Otherwise, they won't be needed.

AIS is developed between different parts of the organization to attain a particular objective [20]. AIS provide help to larger systems; consist of resources, processes, and information system setups [21].

This study resulted that middle managers are negatively affecting the implementation of AIS in companies' located in stock exchange as well as other environmental factors, organizational and cultural factors. So we can conclude that there are many factors affecting the implementation of AIS and without solving these problems, companies won't be able to benefit from the AIS as they are supposed to. Some researches were made to see the impact of AIS on the organizational performance, such as performance management and financial performance [22].

AIS may affect two performances in the firm, the financial performance and managerial performance. When AIS is implemented successfully it could save money and time for shareholders [23]. It could be used also by the financial managers to evaluate the firm's past performance and conclude future plans [24].

As for managerial performance, since AIS is responsible for many important roles in a firm like designing, implementing and monitoring internal control systems through data setting [25]. As a conclusion AIS has a severe effect on financial performance.

\section{RESEARCH OBJECTIVES}

Different reasons may exist behind the lack of use of AIS in Lebanese firms. These reasons are mainly related to the following:

- lack of knowledge

- lack of training

- Cost

This study aims at understanding the aforesaid reasons explaining the minor importance given to IT in accounting departments in local companies. The study's main objectives are:

- Identifying the problems keeping Lebanese firms from using IT in accounting departments

- Spreading awareness about the importance of AIS among firms.

\section{Methodology}

\section{A. Source of Data}

A quantitative approach is used in this research. The first step to be accomplished is data collection, which will enable us to find appropriate information needed for the study. A number of questionnaires will be filled by accountants, chief executive officers and accounting department managers of different Lebanese companies. The questionnaires provide information about the Lebanese companies' knowledge regarding AIS, the problems facing companies adopting AIS and the advantages they can benefit from

\section{B. Sample Selection}

The respondents involved in this survey are accountants, accounting department managers, and chief executive officers working in Lebanese and multinational sales, research and engineering companies and banks. The following are examples of such companies: First National Bank, Foster Clark Products ltd, General Technical Services, IPSOS, Stat, Deliot, Ernest and Young, Pepsi co. and other small Lebanese companies. The response rate was $49 \%$, only 69 questionnaires out of 140 were filled and sent back. Given in the tables below the answers ranging from strongly agreed to strongly disagree. A questionnaire form is given at the end of this paper.

\section{PILOT STUdY}

First of all as we can see in the table safety (0.586), affordability(0.132), adaptation or ease of use(0.371), problems caused by the use of older systems facing technological advancement(0.467), loss of information(0.412), reduction of processing $\operatorname{cost}(0.678)$.

Investment in AIS and campany's size requirements (0.752), and the status of the respondents $(0.058)$ were almost normally distributed according to the responses received from the participants. Few questions which are asked are in the below tables as.

\section{CORRELATION}

According to this research the correlation is significant at the 0.05 level (2-tailed); however when the correlation is above 0.05 level it is considered as insignificant. Correlation statistics are shown inTable I as in below paragraphs:

First, there is high significance between the uses of AIS as a top necessity to a firm and the high accuracy of the data usage (0.000), time saving (0.0.13), good classification of data (0.002), high security (0.000), easy adaptation (0.012), easy application (0.018), reduction of cost (0.034). However, low loss of information, suitable for all companies (0.734), 
size of the company (0.206), cheapness (0.057), status of respondent (0.902) and any type of company (0.407) are insignificant.

TABLE I: PERCENTAGE FREQUENCY DISTRIBUTION

\begin{tabular}{|l|l|l|l|l|l|}
\hline Variables & $\mathbf{S A}^{\mathbf{1}}$ & $\mathbf{A}^{\mathbf{7}}$ & $\mathbf{U}^{\mathbf{8}}$ & $\mathbf{D}^{\mathbf{9}}$ & $\mathbf{S D}^{\mathbf{1 0}}$ \\
\hline $\begin{array}{l}\text { The use of AIS is top } \\
\text { necessity to your firm }\end{array}$ & $56.5 \%$ & $40.6 \%$ & $1.4 \%$ & $1.4 \%$ & $0 \%$ \\
\hline $\begin{array}{l}\text { Data is more accurate } \\
\text { with the use of AIS }\end{array}$ & $66.7 \%$ & $30.4 \%$ & $2.9 \%$ & $0 \%$ & $0 \%$ \\
\hline Use of AIS saves time & $73.9 \%$ & $24.6 \%$ & $1.4 \%$ & $0 \%$ & $0 \%$ \\
\hline $\begin{array}{l}\text { Use of AIS provides } \\
\text { classified data }\end{array}$ & $59.4 \%$ & $39.1 \%$ & $0 \%$ & $1.4 \%$ & $0 \%$ \\
\hline $\begin{array}{l}\text { The use of AIS is much } \\
\text { safer }\end{array}$ & $63.8 \%$ & $36.2 \%$ & $0 \%$ & $0 \%$ & $0 \%$ \\
\hline $\begin{array}{l}\text { Firms can afford easily } \\
\text { the use of AIS }\end{array}$ & $10.1 \%$ & $29.0 \%$ & $26.1 \%$ & $21.7 \%$ & $13.0 \%$ \\
\hline $\begin{array}{l}\text { It's easy for the em- } \\
\text { ployees to adapt with new } \\
\text { AIS }\end{array}$ & $5.8 \%$ & $39.1 \%$ & $21.7 \%$ & $20.3 \%$ & $13.0 \%$ \\
\hline $\begin{array}{l}\text { Having older AIS causes } \\
\text { problems with new AIS }\end{array}$ & $21.7 \%$ & $47.8 \%$ & $21.7 \%$ & $8.7 \%$ & $0 \%$ \\
\hline $\begin{array}{l}\text { Use of AIS may lead to } \\
\text { loss of information }\end{array}$ & $8.7 \%$ & $37.7 \%$ & $23.2 \%$ & $14.5 \%$ & $15.9 \%$ \\
\hline $\begin{array}{l}\text { The use of AIS reduces } \\
\text { cost }\end{array}$ & $18.8 \%$ & $62.3 \%$ & $14.5 \%$ & $4.3 \%$ & $0 \%$ \\
\hline $\begin{array}{l}\text { Investing in AIS requires } \\
\text { less of the company's size }\end{array}$ & $14.5 \%$ & $49.3 \%$ & $18.8 \%$ & $13.0 \%$ & $4.3 \%$ \\
\hline
\end{tabular}

Second, there is a high significance between the accuracy of data using the AIS and time saving (0.000), good classification of data (0.000), high security (0.000). However, cheapness (0.109), easy adaptation (0.260), easily application (0.869), very low loss of information (0.882), reduction of cost (0.224), suitable for all companies, size of the company (0.780), status of respondent $(0.324)$ and any type of company (0.497) are insignificant.

Third, there is a high significance between time saving and good classification of data (0.003), high security (0.000). However, cheapness (0.274), easy adaptation (0.970), easily application (0.511), very low loss of information (0.944), reduction of cost (0.143), suitable for all companies, size of the company (0.308), status of respondent (0.767) and any type of company (0.423) are insignificant.

Fourth, there is a high significance between classification of data and high security (0.000) and reduction of cost (0.001). However, cheapness (0.923), easy adaptation (0.171), easily application $(0.106)$, very low loss of information (0.662), suitable for all companies (0.223), size of the company (0.791), status of respondent (0.493) and any type of company (0.165) are insignificant.

Fifth, there is a high significance between high security of AIS and reduction of cost (0.001). However, cheapness (0.339), easy adaptation (0.296), easily application (0.853), very low loss of information (0.714), suitable for all companies (0.322), size of the company (0.398), status of respondent $(0.745)$ and any type of company $(0.177)$ are insignificant.

Sixth, there is a high significance between cheapness and loss of information (0.000) and easy adaptation (0.000). However, easily application, reduction of cost $(0.681)$, the

\footnotetext{
${ }^{1}$ Strongly agree, ${ }^{7}$ Agree, ${ }^{8}$ Undecided, ${ }^{9}$ Disagree, ${ }^{10}$ Strongly Disagree
}

company (0.386) are insignificant.

Seventh, there is a high significance between easy adaptations from employees to AIS and loss of information (0.000). However, easily application, reduction of cost (0.323), suitable for all companies (0.743), size of the company (0.282), status of respondent (0.985) and any type of company (0.490) are insignificant.

Eighth, there is insignificance between easily application and very low loss of information $(0.735)$, reduction of cost (0.504), suitable for all companies (0.443), size of the company (0.321), status of respondent $(0.198)$ and any type of company (0.613).

Ninth, there is insignificance between loss of information and reduction of cost (0.864), suitable for all companies (0.062), size of the company $(0.168)$, status of respondent (0.702) and any type of company (0.794).

Tenth, there is a high significance between reduction of cost and suitable for all companies (0.024). However, size of the company (0.391), status of respondent (0.055) and any type of the company (0.386) are insignificant.

Eleventh, there is a high significance between suitability and status of respondent (0.007). However, size of the company (0.194) and type of the company (0.547) are insignificant.

Twelfth, there is a high significance between size of company and type of company (0.000). However, status of respondent is insignificant $(0.317)$.

Thirteenth, there is no significance between status of respondent and type of company (0.190).

\section{REGRESSION}

Regression analysis is conducted to find the variables that affect the company's view about the importance of using AIS and their coefficients. A two step method has been used. Firstly, we use the (Enter Method) that showed an explanation power on independent variables of $R^{2}=43.7 \%$. Then, the Stepwise Method is conducted but the explanatory power has decreased to $36.9 \%$. Nevertheless, Stepwise method has defined three independent variables being all significant to explain the variations in the dependent variable.

\section{A. Enter Method Model}

The use of AIS is a top necessity to the firm, equals $(0.736)+(0.345) . \mathrm{USE}^{2}, \mathrm{SAV}^{3}, \mathrm{CLASS}^{4}, \mathrm{SAFE}^{5}, \mathrm{AFFORD}^{6}$, $\mathrm{EAS}^{7}, \mathrm{PROB}^{8}$, INFO LOSS ${ }^{9}, \mathrm{COS}^{10}, \mathrm{SIZ}^{11}, \mathrm{EMP}^{12}$, status of respondent-(0.023).

\section{B. Stepwise Method Model}

The use of AIS is a top necessity to the firm, equals

${ }^{2}$ USE: data is more accurate with the use of AIS $+(0.068)$

${ }^{3}$ SAV: AIS is time saver

${ }^{4}$ CLASS: use of use of AIS provides classification of data+ $(0.297)$

${ }^{5}$ SAFER: AIS is used in firm $+(0.035)$

${ }^{6}$ AFFORD: firms can afford easily the use of AIS - $(0.156)$

${ }^{7}$ EASY: for the employees to adapt with new information system $+(0.160)$

${ }^{8}$ PROB: older systems lead to facing problems with technological advancement-(0.061)

${ }^{9}$ INFO LOSS: having use of accounting system may lead to some loss of information+ $+(0.083)$

${ }^{10}$ COS: the use of AIS reduces cost-(0.014)

${ }^{11}$ SIZ: investing in AIS is requires less of the size of the company-(0.029)

${ }^{12}$ EMP: number of employees $+(0.028)$ 
$(0.112)+(0.317)$ data is more $\mathrm{ACC}^{13}$, its much $\mathrm{SAF}^{14}$. Conclusion and Recommendations.

\section{CONCLUSION}

This study aimed at analyzing the impact of AIS on the performance of organizations. This paper examined the usefulness of AIS in terms to both managerial and the financial performance. AIS is a computerized mean of collecting, entering, and processing data, as well as storing, managing, controlling, and reporting information that can be used in planning and decision making, thus helping the organization achieve its objectives and goals.

AIS is used to focus on recording, summarizing, and validating the data of the business transactions. Summarizing the results, and measuring the research questions on the opinion of the respondents, we conclude that AIS was found to be the variable with the biggest impact on financial performance. So AIS is the most important factor in firms. Also we obtained that financial performance and managerial performance have a huge influence on the overall performance of the organization.

The collection, storage, and processing of financial and accounting data by the AIS have a huge impact on the improvement of the decision making process, and on the performance evaluation, that's through the quality of the accounting and financial information that it provides. AIS also help internal control and the facilitates a company's transactions.

Finally it's important to mention that such systems are available for a relatively low cost, especially when considering that it helps reducing other costs as well as it provides huge time savings. The general conclusion is that the AIS are indeed useful and have a very positive impact on the overall organizational performance.

\section{LIMITATIONS AND RECOMMENDATIONS FOR FUR- THER RESEARCH}

Although the research is carefully conducted, some afterstudy limitations can be listed. Lack of inadequate resources and time are the limitations of this research. The most important constraint that faces our results would be the fast pace of technological advancement. With the new trend of IT, features and new methodologies in accounting both should be studied. Likewise, it is recommended to prepare a survey of a more qualitative nature geared to managers to relate investment in AIS, strategy, and long-term performance indicators. IT security is the key area which can be implemented in AIS in order to have secure AIS. Encryption methods are available for security like to study algo of RSA, 3DES etc. New accounting methods as in cash vs accrual basis should be incoporated while implementing these systems.

\footnotetext{
${ }^{13}$ ACC: with the use of AIS+ (0.385)

${ }^{14}$ SAF: if AIS is used in firm+(0.189), having older systems leads to problems with technological advancement.
}

\section{REFERENCES}

[1] A. F. Borthick and R. L. Clark, "Making accounting information systems work: An empirical investigation of the creative thinking paradigm," Journal of Information Systems, vol. 4, no. 3, pp. 48-62, 1990.

[2] G. Curtis, "Business information systems: analysis, design and practice.wokingham: addison-Wesley publishing company.empirical investigation of the creative thinking paradigm," Journal of Information Systems, vol. 4, no. 3, pp. 48-62, 1995.

[3] M. Rahman and M. Halladay, Accounting Information Systems: Principles, Applications and Future Directions, New Jersey: Prentice Hall, 1988.

[4] J. W. Wilkinson, Accounting Information Systems: Essential Concepts and Applications, 2nd ed. New York: John Wiley \& Sons Inc, 1993.

[5] J. W. Wilkinson, M. J. Cerullo, V. Raval, and B. Wong-On-Wing, Accounting Information Systems: Essential Concepts and Applications, New York: John Wiley and Sons, 2000.

[6] J. Galbraith, Designing Complex Organizations, AddisonWesley, Reading, MA, 1973.

[7] M. Hall, Accounting information and managerial work, accounting organizationsand society, in press, corrected proof, 2009.

[8] J. Chin, W. Barney, and H. O'Sullivan, Hotels: An Industry Accounting and Auditing Guide (Milton Keynes: Accountancy Books), 1995.

[9] P. Collier and A. Gregory. (1995). Strategic management accounting; a UK hotel sector case study. International Journal of Contemporary Hospitality Management [Online]. 7(1), pp. 16-21. Available: http://dx.doi.org/10.1108/09596119510078171

[10] L. Giunipero, K. Pillai, S. Chapman, and R. Clark, "A longitudinal examination of JIT purchasing practices," The International Journal of Logistics Management, Spanish SMEs, vol. 16, no. 1, pp. 51-70, 2005. The International Journal of Digital Accounting Research, vol. 11, pp. 25-43, 2011.

[11] U. E. Grande, P. R. Estebanez, and M. C. Colomina, The impact of Accounting Information Systems (AIS) on Performance Measures: Empirical Evidence in, 2010.

[12] R. Bee and F. Bee, Managing Information and Statistic, Trowbridge: Cromwell Press, 1999.

[13] L. Kren, "Budgetary participation and managerial performance: the impact of information and environmental volatility," Account Review, vol. 67 , pp. 511-26, 1992.

[14] O. A. A. Jawabreh and A. M. A. Alrabei, The Impact of Accounting Information System in Planning, Controlling and Decision-Making Processes in Jodhpur Hotels, 2012.

[15] J. H. Reneau and S. V. Grabski, "A review of research in computerhuman interaction and individual differences within a model for research in accounting information systems," Journal of Information Systems, vol. 2, no. 1, pp. 33-53, 1987.

[16] J. Teng and K. Calhoun, "Organizational computing as a facilitator of operational and managerial decision making: an exploratory study of managers perceptions," Decision Sciences, pp. 673-710, Fall 1996.

[17] A. D. Crescenzi and J. Kocher, "Management support systems: opportunity for controllers," Management Accounting, vol. 65, no. 9, pp. 34-36, 1984.

[18] C. Rohde, "Management accounting and integrated information systems: A literature review," International Journal of Accounting Information Systems. vol. 18, pp. 40-68, 2007.

[19] A. Hopwood, "The archaeology of accounting systems," Accounting, Organizations and Society, vol. 11, pp. 207-234,1987.

[20] M. Salehi, M. Alipour, and M. Ramazani "Impact of IT on firms' financial performance: some Iranian evidence," Global Journal of Management and Business Research, vol. 10, no. 4, pp. 21-29, 2010.

[21] B. Romeney and J. Steinbart, Accounting Information Systems 9th Edition, Prentice Hall Business Publishing, 2003.

[22] R. G. P. McMahon, L. G. Davies, and N. M. Bluhm, “Exploratory modelling of financial reporting and analysis practices in small growth enterprises," The Journal of Small Business Finance, vol. 3, no. 3, pp. 199-214, 1994.

[23] M. S. Zulkarnain, "Accounting information systems (AIS) and knowledge management: a case study department of accounting and finance, faculty of economics and management university Putra Malaysia," American Journal of scientific research, 2009.

[24] M. Sadia, "The impact of competitive advantage on organizational performance," European Journal of Business and Management, vol. 3, no. 4, 2011.

[25] O. Vitez, and H. H. Baligh, "Organization structures: theory and design, analysis and prescription," Information and Organization Design Series, New York: Springer, 2011. 


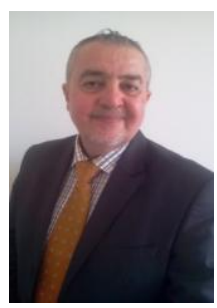

Pierre Al-Khoury was born in Byblos, Lebanon August 12, 1961. Ph.D. in Business Administration, AABFS-an Arab League Institute, Jordan. Masters in Money \& Banking, American University of Beirut (AUB).

Pierre is the chairman of Management Studies Department (2007-present), Rafik Hariri University, Mechref, Lebanon. Previously Economic researcher at the Central Bank of Kuwait.

Pierre has published the following Book: A Guide to Quality Audit and Accreditation in Higher Education, 2008. He also published a paper titled "Financial Assessment of Water Harvesting Techniques as Feasible Environmental and Economical alternative solutions to Large Dams: The Case of the Western Slopes of Mount Lebanon", progress in Environmental Sciences and Technology, proceedings of the 2011 International Symposium, Dongguan, China, Science Press .His Research aera includes Cost Analysis and General Business.

Pierre Al-khoury is an honorary board member of the American Academy of Finanacial Management.

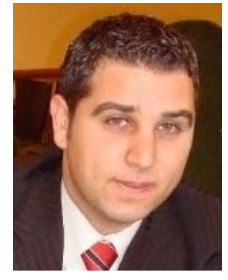

Khalil Ghazzawi was born in El-Minieh, Lebanon, October 18, 1980. Ph.D. in Management, University of Montpellier I, France. Masters in Management Information Systems, Lebanese University.

Khalil is the coordinator of Business Departement (2010-present), Rafik Hariri University, North Campus, Lebanon.

Khalil has published a paper titled "The Marketing of Islamic Banking in Lebanon", International Islamic Banking, Finance and Investment Conference, World Business Institute (WBI), Australia and London, December 2011, Kuala Lumpur, Malaysia. Khalil is also a case study writer for Pearson Education. His research interests are e-Business, General Management, Marketing and International Business.

Khalil Ghazzawi is a member of the advisory Board of the International Management Consultancy Board. 